\title{
Üniversite Öğrencilerinin Probiyotik Bilgi Düzeyi ve Tüketim Durumlarının Belirlenmesi
}

\author{
Batuhan Horasan $^{1 *}$, Özgür Sevinç ${ }^{2}$, Nevzat Atalay Çelikyürek ${ }^{3}$ \\ 1* İstanbul Üniversitesi, Sağlık Bilimleri Enstitüsü, Halk Sağlığı (Dr), İstanbul, Turkey, (https://orcid.org/my-orcid?orcid=0000-0003-1303-8465 ), batuhan horasan \\ @ hotmail.com \\ ${ }^{2}$ Pamukkale Üniversitesi, Tıp Fakültesi, Halk Sağlığı Bölümü,, Denizli, Turkey, (https://orcid.org/0000-0002-3231-8123 ), ozgursevinc@ gmail.com \\ ${ }^{3}$ Pamukkale Üniversitesi, Tıp Fakültesi, Halk Sağlığı Bölümü,, Denizli, Turkey, (https://orcid.org/0000-0001-9731-8880), atalaycelikyurek@gmail.com
}

(İlk Geliş Tarihi 4 Ekim 2021 ve Kabul Tarihi 16 Aralık 2021)

(DOI: $10.31590 /$ ejosat.999946)

ATIF/REFERENCE: Horasan, B., Sevinç, Ö., Çelikyürek, NA. (2021). Üniversite Öğrencilerinin Probiyotik Bilgi Düzeyi ve Tüketim Durumlarının Belirlenmesi. European Journal of Science and Technology, (31), 446-453.

$\ddot{O} \mathbf{z}$

Geçmişten günümüze probiyotik üzerine yapılan çalışmalar, genelde hastalık üzerinde yoğunlaşırken, probiyotik besinlerin tüketim durumları, probiyotik bilgi düzeyleri ve probiyotik bilgi düzeyinin probiyotik besin tüketimi üzerinde etkisini gösteren çalışmalar sınırlı sayıdadır. Bu çalışma, Pamukkale Üniversitesi öğrencilerinin probiyotik bilgi düzeyleri ve tüketim durumlarının belirlenmesi amacıyla Ekim-Kasım 2020 tarihleri arasında Pamukkale Üniversitesi Eğitim Fakültesi ve Sağlık Bilimleri Fakültesi öğrencilerinde öğrenim gören 607 öğrenci ile gerçekleştirilmiştir. Kesitsel tipte olan çalışmada örneklem alınmaksızın tüm fakülte öğrencilerine ulaşılması amacıyla çevrim içi (online) anket yöntemi uygulanmıştır. Öğgrencilerin \%12,4'üne ulaşılmıştır. Verilerin değerlendirilmesinde SPSS paket programı kullanılmıştır. Tanımlayıcı istatistikler kategorik değişkenler için sayı, yüzde (\%); sürekli değişkenler için aritmetik ortalama $(\overline{\mathrm{X}})$, ve standart sapma $(\mathrm{S})$ ile verilmiştir. Kategorik değişkenlerin karşılaştırılmasında Ki-kare testi

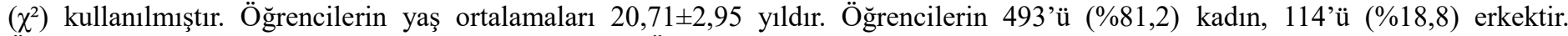
Öğrencilerin probiyotik bilgi düzeyi orta düzeydedir. Öğrencilerin \%73,5’i probiyotik besin tükettiğini belirtmiştir. Probiyotik bilgi düzeyi yüksek olanların daha çok probiyotik besin tükettiği belirlenmiştir ( $U=25339,0 ; p<0,001)$. Kız öğrencilerin probiyotik besin tüketme durumu erkek öğrencilere göre daha yüksek olduğu saptanmıştır $\left(\chi^{2}=21,645 ; p<0,001\right)$. Probiyotik besin tüketenlerin \%66,4'ü ambalajında "probiyotik" ibaresi bulunan yoğurt tükettiği, \%73,8’i sindirim sistemine faydalı etkisi görmesi nedeniyle tükettiği, \%38,1'i bu besinleri günde $1 \mathrm{kez}$ tükettiği, \%47,5'i bu besinleri internetten öğrendiği, \%73,8'i bu besinlerin etiketi ve içeriğine dikkat ettiği, \%83,4'ü bu besinleri buzdolabında sakladığ $1 \% 82,5$ 'i bu besinleri tüketmeleri için çevresine önerdiği belirlenmiştir. Probiyotik besin tüketmeyenlerin \%62,1'i ne olduğunu bilmemesi nedeniyle tüketmediği saptanmıştır. Bu bakımdan kişilerin probiyotik bilgi düzeyinin arttırılması probiyotik besin tüketimi üzerinde olumlu etkileri olabileceği düşünülmektedir.

Anahtar Kelimeler: Probiyotik, üniversite öğrencileri, tüketim durumları, bilgi düzeyi.

\section{Determination of Probiotic Knowledge Level and Consumption Status of University Students}

\begin{abstract}
While studies on probiotics from past to present have generally focused on the disease, studies showing the effects of probiotic foods consumption status, probiotic knowledge levels and probiotic knowledge level on probiotic food consumption are limited. This study was carried out with 607 students studying at Pamukkale University Faculty of Education and Faculty of Health Sciences between October and November 2020 to determine the probiotic knowledge levels and consumption status of Pamukkale University students. In the cross-sectional study, an online survey method was applied to reach all faculty students without sampling. $12.4 \%$ of the students have been reached. SPSS package program was used to evaluate the data. Descriptive statistics for categorical variables number, percent $(\%)$; for continuous variables are given with arithmetic mean $(\overline{\mathrm{X}})$, and standard deviation $(\mathrm{S})$. Chi-square test $\left(\chi^{2}\right)$ was used to compare categorical variables. The mean age of the students is $20.71 \pm 2.95$ years. Of the students, $493(81.2 \%)$ were female and $114(18.8 \%)$ were male. The probiotic knowledge level of the students is moderate. $73.5 \%$ of the students stated that they consume probiotic food. It was determined that those with high probiotic knowledge consumed more probiotic foods (U=25339.0; $\mathrm{p}<0.001)$. It was determined that female students' consumption of probiotic food was higher than male students $\left(\chi^{2}=21,645 ; \mathrm{p}<0.001\right)$.
\end{abstract}

* Corresponding Author: batuhan horasan @hotmail.com 
Of those who consume probiotic food, $66.4 \%$ consume yogurt with the expression "probiotic" on its package, $73.8 \%$ consume it because it has a beneficial effect on the digestive system, $38.1 \%$ consume these foods once a day, $47.5 \%$ of learned these foods from the internet, $73.8 \%$ paid attention to the label and content of these foods, $83.4 \%$ kept these foods in the refrigerator, and $82.5 \%$ recommended these foods to their surroundings to consume. It was determined that $62.1 \%$ of those who did not consume probiotic food did not consume it because they didn't know what it was. Therefore, it is thought that increasing the probiotic knowledge level of people may have positive effects on probiotic food consumption.

Keywords: Probiotic, university students, consumption status, level of knowledge.

\section{Giriş}

Beslenme, insanın büyüme, gelişme, sağlıklı ve üretken olarak uzun yıllar yaşaması için gerekli olan besin öğelerini yeterli miktarda alıp vücudunda kullanmasıdır. $\mathrm{Bu}$ öğelerin gerektiğinden eksik veya fazla alınmasının, sağlığı olumsuz yönde etkilediği bilimsel çalışmalarda gösterilmiştir (Çalıştır vd 2005). Bu durum günümüzde sağl1klı beslenme isteğini arttırmış, kişilerin besin destek ürünlerine ve fonksiyonel besinlere olan merakının artmasına neden olmuştur (Yabancı ve Şimşek 2007). Fonksiyonel besinler yapılarında bulunan bileşenler ile vücudun gerekli besin ihtiyaçlarını karşılamasına ek olarak, sağlığı geliştiren, hastalıklardan korunmada etkili olabilen ve yaşam kalitesini artıran besinlerdir (Demir ve Aktaş 2018). Fonksiyonel besinler sinıfında probiyotik besinler önemli yer tutmaktadır (Kağan vd 2019).

Probiyotik kelimesi Yunanca kökenli olup "yaşam için” anlamına gelmektedir (Gomes ve Malcata 1999). Probiyotikler hakkında önemli çalışmalar yapan Elie Metchnikoff, Bulgar halkıyla diğer ulusları karşılaştırıp, Bulgarların daha uzun süre yaşadığını belirtmiş ve bu durumun nedenini canlı bakteri içeren süt ürünleri tüketimi olduğunu ifade etmiştir (Parkes 2007). Metchnikoff'tan sonra probiyotikler üzerine birçok araştırma yapılmış olup günümüzde ISAPP (Probiyotik ve Prebiyotikler Uluslararası Bilimsel Derneği) tarafından değiştirilen hali bilimsel ve medikal literatürde kullanılmaktadır. Bu tanımlama; "yeterli miktarda alındığında konakçının sağlığına olumlu etkileri olan, yaşayan organizmalar" şeklindedir (İmamlı ve Akça 2018).

Probiyotik mikroorganizmaların büyük çoğunluğunu, Lactobacillus ve Bifidobacterium ailesi oluşturmaktadır. Probiyotik özellikleri kanıtlanmış tek maya türü ise $S$. cerevisiae Boulardii'dir (Çoşkun 2014). Bir mikroorganizmanın probiyotik olarak sayılabilmesi için bazı özelliklere sahip olması gerekir. Bunlar, insan ve hayvanlarda kullanıldığında yan etki oluşturmama, bağırsak hücrelerine tutunabilme ve bağırsaklarda kolonize olabilme, besinlere ilave edildiğinde canlılığını sürdürme ve aktivitesini koruyabilme, konak için patojen olmama, normal florayı bozmadan patojen bakterileri inhibe etme, antibiyotiğe karşı dirençli olma ve çok suşlu ürünlerin üretiminde kullanılma gibi özelliklerdir (Bakır 2012).

Probiyotiklerin insan sağlığı açısından; immün sistemin uyarılması ve regülasyonu, enfeksiyonları önleme ve tedavi etme, inflamatuvar bağırsak hastalıklarının tedavisi ve atakların önlenmesi, laktoz intoleransının önlenmesi, kanser oluşumunun azaltılması, kan kolesterol seviyesinin düşürülmesi, çocuklarda alerjik reaksiyonların ortaya çıkışının geciktirmesi, kadınlarda vajinal ve üriner sistem enfeksiyonlarının tedavi edilmesi ve önlenmesi gibi olumlu etkileri bulunmaktadır (Derin ve Keskin 2013, Usta ve Urganc1 2014).
Probiyotiklerin etkisi probiyotiğin türüne, kullanılan suşa, dozuna ve veriliş yoluna göre değişmektedir.

$\mathrm{Bu}$ sebeple, bir probiyotik bakterideki belirlenen etkiler bütün probiyotik mikroorganizmalar için geçerli değildir. Probiyotikler sıklıkla güvenilir olması ve iyi tolere edilmesi nedeniyle genellikle ağız yoluyla kullanılmalıdır (Çoşkun 2014). Bununla birlikte probiyotik mikroorganizmalar içeren probiyotik besinler düzenli tüketilmelidir (Kundakçı ve Ergönül 2006).

Üniversite öğrencilerinin, çocukluk dönemi sonrası üniversite eğitiminin başlaması ile alışkın oldukları aile ortamından ayrılmaları, çevresel etkenlere daha açı hale gelmeleri ve daha çok kendi seçimlerini kendileri yapmaları ile beslenmelerinde yeni bir dönem başlamaktadır. $\mathrm{Bu}$ sebeple üniversite öğrencilerinin beslenmelerine yönelik çalışmalar önem kazanmıştır (Aydın vd 2010). Ancak probiyotiklerle ilgili yapılan çalışmalar, genelde hastalık üzerinde yoğunlaşırken, probiyotiklerin tüketim durumlarını ve bilgi düzeylerini gösteren çalışmalar sınırlı sayıdadır. Bu noktada çalışmamızın literatüre katkı sağlayacağı düşüncesindeyiz.

$\mathrm{Bu}$ çalışma Pamukkale Üniversitesi öğrencilerinin probiyotik bilgi düzeyleri ile probiyotik besin tüketim durumlarının belirlenmesi ve probiyotik bilgi düzeyi ve cinsiyete göre probiyotik besin tüketim durumunu incelemek için yapilmıştır.

\section{Materyal ve Metot}

\subsection{Araştırma Yöntemi ve Örneklemi}

Araştırma; Ekim-Kasım 2020 tarihleri arasında Pamukkale Üniversitesi Sağlık Bilimleri Fakültesi ve Eğitim Fakültesinde okuyan $(n=4871)$ lisans öğrencilerinin, probiyotik besinler hakkındaki bilgi düzeyleri ve tüketim durumlarını saptamak amacı ile yapılmıştır. Araştırmanın evrenini Sağlık Bilimleri Fakültesi ve Eğitim Fakültesinde okuyan öğrenciler oluşturmuştur. Araştırmada örneklem seçimine gidilmemiştir. Sağlık Bilimleri Fakültesi ve Eğitim Fakültesi'nde okuyan bütün öğrencilerin çalışmaya katılması hedeflenmiş olup 607 öğrenciye ulaşılmıştır. Veriler, araştırmacı tarafından ilgili literatürden yararlanılarak ve uzman görüşleri alınarak hazırlanmış anket formuyla çevrim içi (online) anket yöntemiyle toplanmıştır. Anket formu dört bölümden oluşmakta olup, ilk bölüm öğrencilerin sosyodemografik özelliklerini içeren sorulardan, ikinci bölüm öğrencilerin probiyotiklerle ilgili bilgi düzeyini ölçmek amacıyla literatür taranarak oluşturulmuş sorulardan oluşmaktadır. Literatür taranarak oluşturulmuş 17 soruluk bilgi sorularının cevapları 'katılıyorum', 'katılmıyorum', 'bilmiyorum' şeklindedir. Katılımcılar doğru önermelere katıldığında 1, katılmadığında ya da bilmediğinde 0 puan almaktadırlar (14. ve 16. sorularda katılmayanlar 1 puan almaktadırlar). Anket formunda alınabilecek maksimum puan 17 , minimum puan ise 0 'dır. Yüksek puan probiyotiklere yönelik 
daha yüksek bilgi düzeyini içermektedir. Üçüncü bölüm probiyotik besinler hakkındaki tutum ve davranış özelliklerini içeren sorulardan oluşmaktadır. Dördüncü bölüm ise toz, tablet veya saşe formundaki gıda takviyesi probiyotik ürünlerle ilgili sorulardan oluşmaktadır.

\subsection{Verilerin Değerlendirilmesi}

Verilerin değerlendirilmesinde SPSS 17.0 paket programı kullanılmıştır. Tanımlayıcı istatistikler kategorik değişkenler için sayı, yüzde (\%); sürekli değişkenler için aritmetik ortalama $(\bar{X})$ ve standart sapma (S) ile verilmiştir. Kategorik değişkenlerin karşılaştırılmasında Ki-kare testi kullanılmıştır. Testte verilen yanıtların normal dağılıma uygun olup olmadıkları KolmogorovSmirnov analiz yöntemi ile test edilmiştir. Bağımsız grup farklılıklarının karşılaştırılmasında Mann-Whitney $U$ testi kullanılmıştır. İstatistiksel anlamlılık düzeyi $\mathrm{p}<0,05$ anlamlı olarak kabul edilmiştir.

\section{Araştırma Sonuçları ve Tartışma}

3.1. Öğrencilere ait Sosyo-Demografik Özellikler

Çalışmaya katılan öğrencilerin yaş ortalaması $20,71 \pm 2,95$ yıldır. Öğrencilerin \%81,2'si kadın \%18,8'i erkektir. Öğrencilerin \%75,0'1 Eğitim Fakültesi’nde \%25,0'1 Sağlık Bilimleri Fakültesi'nde olduğu görülmektedir. (Tablo 1).

Tablo 1. Katılımcıların Sosyo-Demografik Özellikleri $(N=607)$

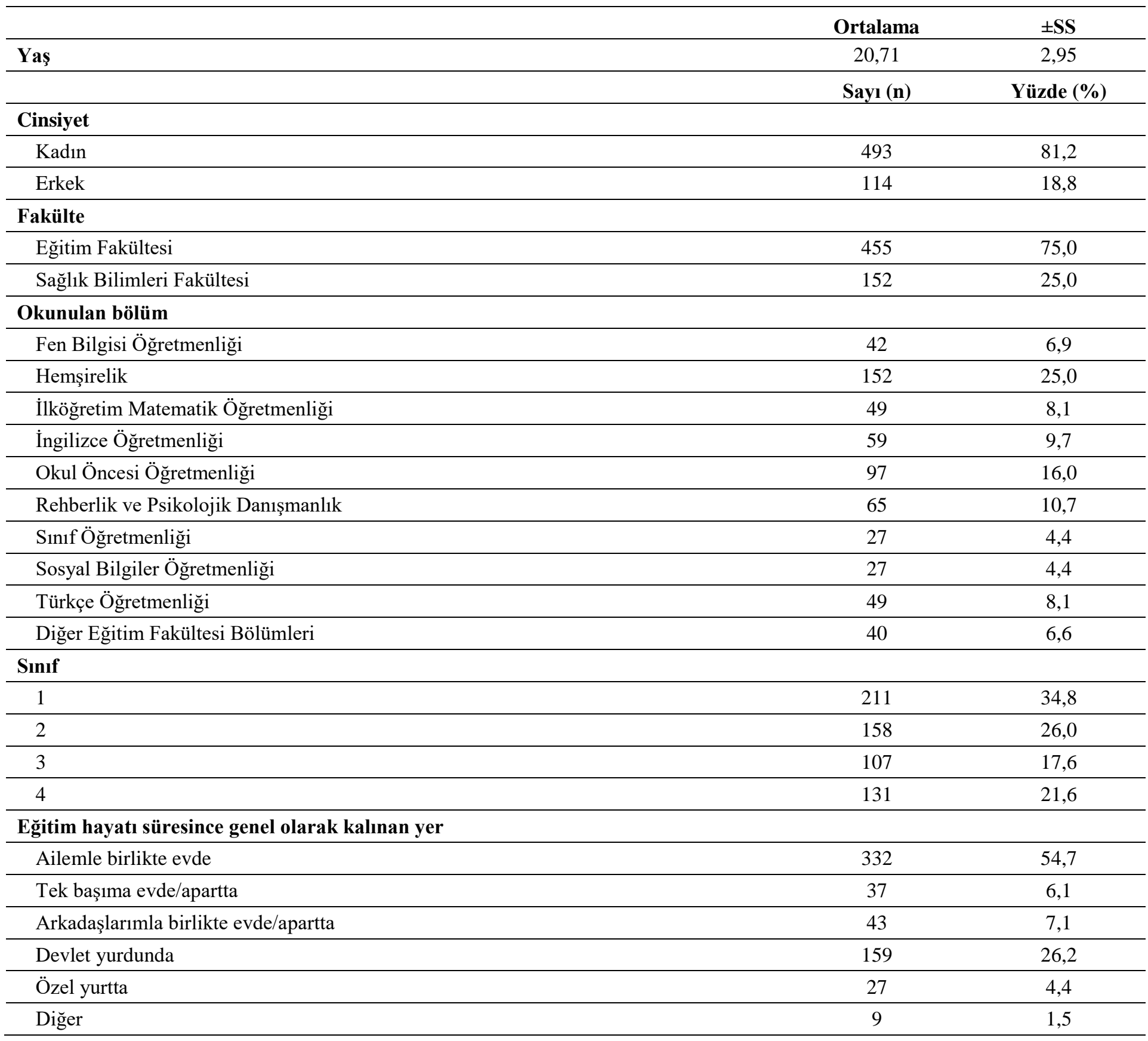


Diğer Eğitim Fakültesi bölümleri Beden Eğitimi ve Spor Öğretmenliği, Bilgisayar ve Öğretim Teknolojileri Öğretmenliği, Müzik Öğretmenliği, Özel Eğitim Öğretmenliği ve Resim İş Öğretmenliği bölümlerinden oluşmaktadır.

\section{2. Öğrencilerin Probiyotikler Hakkında Bilgi Düzeyi}

Öğrencilerin probiyotik ile ilgili 17 sorudan elde ettikleri ortalama bilgi düzeyi puanı 8,44 ve ortanca bilgi düzeyi puanı 9 olarak saptanmıştır. Probiyotik bilgi düzeyini ölçmeyi sağlayan sorulardan en az 0 , en fazla 17 puan elde edilebilecekleri göz önünde bulundurulduğunda orta düzeyde bilgi düzeyine sahip oldukları belirlenmiştir (Tablo 2). Zemzemoğlu ve arkadaşlarının üniversite öğrencileri üzerinde yaptığı araştırmada, öğrencilerin $\% 68,6$ 's1 probiyotiklerle ilgili orta seviyede bilgi düzeyine sahip olduğu belirtmiştir (Zemzemoğlu vd 2019).
Aslantürk'ün beslenme ve diyet kliniğine başvuran kişiler üzerinde yaptığ 1 çalışmada "probiyotik" terimini tanımlayabilme düzeyinin \%85 oranında olduğu belirtilmiştir (Aslantürk 2019). Stanczak ve Heuberger'in bölge halkı üzerinde yaptığı çalışmada probiyotik terimini doğru olarak bilen katılımcı oranı $\% 43,9$ olarak belirlenmiștir (Stanczak ve Heuberger 2009). Payahoo ve arkadaşlarının tıp öğrencileri üzerinde yaptığı çalışmada öğrencilerin probiyotik bilgi sorularından yola çıkarak \%51'inin iyi probiyotik bilgi düzeyine sahip olduğu belirtilmiştir (Payahoo 2012). Anukam ve arkadaşlarının doktorlar üzerinde yaptığı bir çalı̧̧mada katılımcıların \%95,2'si probiyotik terimini bilmediğini belirtmiştir (Anukam vd 2006). Bu bakımdan literatürde farklı sorgulama yöntemleri kullanılarak bulunan probiyotik bilgi düzeyi sonuçları çeşitlilik göstermektedir.

Tablo 2. Çalışmaya katılan öğrencilerin probiyotikler ile ilgili bilgi düzeyi durumu

\section{3. Öğrencilerin Probiyotik Ürün Tüketim Durumları ve Alışkanlıklarına İlişkin Bilgiler}

Çalışmamızda öğrencilerin \%73,5'inin probiyotik besin tükettiği, \%26,5'inin ise probiyotik besin tüketmediği saptanmıştır. Öğrencilerin \%73,8'i, probiyotik besin tüketim nedeni olarak sindirim sistemine faydalı etkisinden dolayı tüketenler oluşturmaktadır (Tablo 3). Çalışmamızda öğrencilerin probiyotik besin tüketim nedeni olarak en çok sindirim sistemine faydalı etkisinden dolayı tüketenler oluşturmaktadır.
Öztürk'ün yaptığı çalışmada katılımcıların \%88,4'ü probiyotik besinleri bağırsak sağlığına faydalı olması nedeniyle tükettiğini belirtmiştir (Öztürk 2018). Zeren'in yaptığı çalışmada katılımciların \%61,7'si sindirim sistemine faydalı bulması nedeniyle probiyotik besin tüketmektedir (Zeren 2015). Balkış’ın yaptığ 1 çalışmada katılımcıların \%67,9'u sindirim sistemi sorunları nedeniyle probiyotik besin tüketmektedir (Balkış 2011). Şengün ve arkadaşlarının yaptığı çalışmada katılımcıların \%63,9'unun sindirim sistemine faydası olması nedeniyle probiyotik besin tükettiği saptanmıştır (Şengün vd 2020). Çalışmamız en sık probiyotik besin tüketilme nedeni bakımından yapılan diğer çalışmalar ile benzerlik göstermektedir.

Tablo 3. Öğrencilerin probiyotik besin tüketme nedenleri

\begin{tabular}{|c|c|c|}
\hline Probiyotik besin tüketme nedenleri*,** & $\begin{array}{c}\text { Sayı } \\
(\mathbf{N})\end{array}$ & $\begin{array}{c}\text { Yüzde } \\
(\%)\end{array}$ \\
\hline Sindirim sistemime faydalarını gördüm. & 329 & 73,8 \\
\hline Kansere karşı koruyucu olduğunu düşünüyorum. & 60 & 13,5 \\
\hline Lezzetli buluyorum. & 233 & 52,2 \\
\hline Bağışıklık sistemini güçlendiriyor. & 315 & 70,6 \\
\hline Yakınlarım önerdiği için kullanıyorum. & 64 & 14,3 \\
\hline Probiyotik tüketimimde reklamların etkisinde kalıyorum. & 33 & 7,4 \\
\hline Diyetisyenim veya doktorum önerdiği için tüketiyorum. & 56 & 12,6 \\
\hline Diğer & 5 & 1,1 \\
\hline
\end{tabular}

* Birden fazla seçenek işaretlenebileceği belirtilmiştir.

** Probiyotik besin tüketenler üzerinden hesaplanmıştır.

Öğrencilerde probiyotik besin tüketme nedeni olarak; \%62,1'i probiyotiğin ne olduğunu bilmediği için tüketmediğini belirtmiştir (Tablo 4). Derin ve Keskin'in üniversite öğrencileri üzerinde yaptığı çalışmada, probiyotik ürün tüketmeyen öğrencilerin \%49,2'si probiyotik besinin ne olduğunu bilmediği için tüketmediği belirtilmiştir (Derin ve Keskin 2013). Aydın ve arkadaşlarının üniversite öğrencileri üzerinde yaptıkları e-ISSN: 2148-2683 çalışmada probiyotik ürün tüketmeyen öğrencilerin \%54,7'si bu ürünleri bilmediklerini belirtmişlerdir (Aydın vd 2010). Yapılan çalışmalardan yola çıkarak probiyotik besin tüketmeme nedeni olarak başlıca sebep ne olduğunun bilinmemesidir. Bu bakımdan kişilerin probiyotik bilgi düzeyinin artırılmasının probiyotik besin tüketimi üzerinde olumlu etkiler oluşturabileceği düşünülmektedir. 
Tablo 4. Öğrencilerin probiyotik ürünleri tüketmeme nedenleri

\begin{tabular}{lcc}
\hline Probiyotik besin tüketilmeme nedenleri ${ }^{*}, * *$ & $\begin{array}{c}\text { Sayı } \\
(\mathbf{N})\end{array}$ & $\begin{array}{c}\text { Yüzde } \\
(\%)\end{array}$ \\
\hline Ne olduğunu bilmeme & 100 & 62,1 \\
\hline Doğal bulmama & 10 & 6,2 \\
\hline İhtiyaç duymama & 43 & 26,7 \\
\hline Pahalı bulma & 15 & 9,3 \\
\hline Lezzetsiz bulma & 12 & 7,5 \\
\hline
\end{tabular}

* Birden fazla seçenek işaretlenebileceği belirtilmiştir.

** Probiyotik besin tüketmeyenler üzerinden hesaplanmıştır.

Probiyotik besin içerisinde raf ömrü bitene kadar yeterli miktarlarda canlı mikroorganizma içeren besindir (Yalçın ve Yalçın 2014). Türk Gıda Kodeksi Etiketleme Yönetmeliği'ne göre bir gıdanın probiyotik olarak tanımlanabilmesi için en az $1 \times 10^{6}$ koloni oluşturan birim (kob)/gram probiyotik mikroorganizma içermesi gerekmektedir (Gıda, Tarım ve Hayvancilık Bakanlığı, 2011). Probiyotik bir besin birden fazla bakteri türü ve bunların suşlarını içerebilmektedir (Bozkurt ve Aslım 2004). Bu durumlar probiyotik besin seçimini oldukça önemli hale getirmektedir. Çalışmamızda probiyotik besin tüketen öğrencilerin en fazla oranda tükettiği probiyotik besin, ambalajında "probiyotik" ibaresi bulunan yoğurttur (Tablo 5). Eser'in bölge halkı üzerinde yaptığı çalışmada probiyotik olarak en fazla tüketilen ürünün yoğurt olduğu saptanmıştır (Eser 2017). Çalışmamız en çok tüketilen probiyotik besin çeşidi bakımdan yapılan diğer çalışma ile benzerlik göstermektedir.

Çalışmamızda probiyotik besinler tüketen öğrencilerin $\% 38,1$ 'i günde $1 \mathrm{kez}, \% 24$ 'ü haftada bir kez, $\% 15,9$ 'u günde 2-3 kez, \%12,6's1 nadiren ve \%9,4'ü ayda 1-3 kez tüketmektedir (Tablo 5). Benzer şekilde Zeren'in yaptığı çalışmada probiyotik besin tüketim sıklıkları; \%24,4'ü günde $1 \mathrm{kez}, \% 23,3$ 'ü nadiren, $\% 19,8$ 'i haftada bir kez, $\% 17,4$ 'ü ayda $1-3$ kez ve $\% 15,1$ 'i günde 2-3 kez tüketmektedir (Zeren 2015). Bağırsaktaki kolonizasyon geçici olması sebebiyle probiyotiklerin bağırsaktaki koruyucu etkisinin devam edebilmesi için, düzenli tüketilmelidir (Ceyhan ve Alıç 2012). Bu bakımdan çalışmamızda nadiren probiyotik besin tüketenlerin oranı diğer çalışmadan az olması sevindirici bir sonuçtur.

Çalışmamızda probiyotik besini öğrenme kaynağının en fazla oranda internet olduğu saptanmıştır (Tablo 5). Sevilmiş’in, yapmış olduğu çalışmada katılımcıların \%32'si fonksiyonel ürünleri en fazla televizyon reklamlarından duyduğunu belirtmiştir (Sevilmiş 2008). Bireylerin herhangi bir ürünü tercih etmesinde televizyon reklamlarının ve internetin etkili bir rol oynadığı yapılan çalışmalardan görülmektedir. Bu bakımdan çalışmamızın yapılan çalışmadan farklı olarak en fazla oranda internet kullanımının artması, günümüzde internetin bilgiye kolay ulaşılmasını sağlamasından dolayı ön plana çıkardığı düşünülmektedir.

Çalışmamızda öğrencilerin probiyotik besin satın alırken, $\% 73,8$ 'i besin etiketi ve içeriğine, \%55,6's1 markasına, \%34,8'i fiyatına, \%9,6's1 görünüşüne ve \%2,5'i diğer kriterlere dikkat etmektedir (Tablo 5). Aslantürk'ün beslenme ve diyet kliniğine gelen kişiler üzerinde yaptığı çalışmada, probiyotik besin satın alırken \%64,2 oranıyla besin etiketi ve içeriğine dikkat edildiği belirtilmiştir (Aslantürk 2019). Eser'in bölge halkı üzerinde yaptığı çalışmada katılımcıların probiyotik besinler ile ilgili en fazla dikkat ettiği kriter etiket bilgileridir (Eser, 2017). Bu bakımdan çalışmamız yapılan diğer çalışmalar ile benzerlik göstermektedir. Tüketicilerin alacağı besinin etiket bilgilerini okuması başlıca sorumluluklarındandır. Bu bakımdan kişilere besin etiketi okuma alışkanlığı edinimi açısından gerekli eğitimler yapılarak besin etiketi ve içeriği alıskanlığının artırılması gerekmektedir.

Çalışmamızda saklama biçimi olarak en fazla buzdolabı tercih edilmektedir (Tablo 5). Buzdolabında saklanan probiyotik besinlerin raf ömrü 3-6 hafta arasında değişkenlik gösterebilmektedir. $\mathrm{Bu}$ besinler buzdolabında saklanmayanlara göre daha uzun süre muhafaza edilebilmektedir (Bilginer ve Çetin 2019). Bu sebeple öğrencilerin saklama biçimi olarak çoğunluğunun probiyotik besinleri dolapta değil de buzdolabında saklamaları olumlu bir sonuç olarak düşünülebilir.

Çalışmamızda öğrencilerin büyük bir çoğunluğu probiyotik besinleri çevresine önermektedir (Tablo 5). Çevreye önerme durumunu etkileyen birden fazla faktör olacağı düşünülmekle birlikte temel neden olarak kişilerin probiyotiklerin kendisine fayda sağlaması sebebiyle çevresine önerdiği düşünülmektedir.

Tablo 5. Öğrencilerin Probiyotik Besin Tüketim Alıskanlıklarına İlişkin Bulgular

Sayı (N) Yüzde (\%)

\begin{tabular}{lcc}
\hline Probiyotik besin tüketenler & & \\
\hline Evet & 446 & 73,5 \\
\hline Hayır & 161 & 26,5 \\
\hline Tüketilen probiyotik besin çeşitleri*,** & 296 & 66,4 \\
\hline Ambalajında "probiyotik" ibaresi bulunan yoğurt & 197 & 44,2 \\
\hline Ambalajında "probiyotik" ibaresi bulunan süt & 450
\end{tabular}




\begin{tabular}{|c|c|c|}
\hline Ambalajında "probiyotik" ibaresi bulunan peynir & 147 & 33,0 \\
\hline Ambalajında "probiyotik" ibaresi bulunan kefir & 188 & 42,2 \\
\hline Ambalajında "probiyotik" ibaresi bulunan ayran & 174 & 39,0 \\
\hline Diğer & 35 & 7,8 \\
\hline \multicolumn{3}{|l|}{ Probiyotik besin tüketim sıklığı** } \\
\hline Günde 1 kez & 170 & 38,1 \\
\hline Günde $2-3 \mathrm{kez}$ & 71 & 15,9 \\
\hline Haftada $1 \mathrm{kez}$ & 107 & 24,0 \\
\hline Ayda 1-3 kez & 42 & 9,4 \\
\hline Nadiren & 56 & 12,6 \\
\hline \multicolumn{3}{|l|}{ Probiyotik besinleri öğrenme kaynağı*,*** } \\
\hline Uzman (Doktor veya diyetisyen) & 148 & 33,2 \\
\hline Arkadaş, tanıdık, aile vb. & 195 & 43,7 \\
\hline Eğitim, konferans, bilimsel toplantı & 112 & 25,1 \\
\hline Eczane ve satış noktaları & 64 & 14,3 \\
\hline İnternet & 212 & 47,5 \\
\hline Diğer & 5 & 1,1 \\
\hline \multicolumn{3}{|c|}{ Probiyotik besin satın alırken dikkat edilen kriterler*,*** } \\
\hline Fiyat & 155 & 34,8 \\
\hline Marka & 248 & 55,6 \\
\hline Besin etiketi, içeriği & 329 & 73,8 \\
\hline Görünüş & 43 & 9,6 \\
\hline Diğer & 11 & 2,5 \\
\hline \multicolumn{3}{|l|}{ Probiyotik besinlerin saklanma biçimi*** } \\
\hline Buzdolab1 & 372 & 83,4 \\
\hline Dolap & 43 & 9,6 \\
\hline Saklamıyorum hemen tüketiyorum & 31 & 7,0 \\
\hline \multicolumn{3}{|c|}{ Probiyotik besinleri tüketmeleri için çevresine önerme durumu ${ }^{* *}$} \\
\hline Evet & 368 & 82,5 \\
\hline Hayır & 5 & 1,1 \\
\hline Kararsızım & 73 & 16,4 \\
\hline
\end{tabular}

* Birden fazla seçenek işaretlenebileceği belirtilmiştir.

** Probiyotik besin tüketenler üzerinden hesaplanmıştır.

Çalışmamızda cinsiyete göre probiyotik besin tüketme durumuna bakıldığında kadınların daha yüksek oranda probiyotik besin tükettiği görülmüştür ve bu fark istatistiksel olarak anlamlıdır ( $\left.\chi^{2}=21,645 ; \mathrm{p}<0,001\right)$ (Tablo 6). Yabancı ve Şimşek'in yapmış oldukları çalışmada kız öğrenciler erkek öğrencilere göre daha fazla probiyotik ürün tüketmektedir $(p<0,05)$ (Yabancı ve Şimşek 2007). Zeren'in yaptığı çalışmada kadınların erkeklere göre daha fazla probiyotik besin tükettiği saptanmıştır $(p<0,05)($ Zeren 2015).

Benzer şekilde Aydın ve arkadaşlarının yaptığı çalışmada kız ögrencilerin daha fazla probiyotik besin tükettiği belirlenmiştir $(\mathrm{p}<0,05)$ (Aydın vd 2010). Çalışmamız yapılan diğer çalışmalarla benzerlik göstermektedir. Bu durum kadınların besin tüketme durumu, sağlık, beslenme ve fiziksel görünüme erkeklerden daha fazla önem vermelerine bağlanabilir.

Tablo 6. Öğrencilerin cinsiyete göre probiyotik besinleri tüketim durumları

\begin{tabular}{|c|c|c|c|c|c|}
\hline & \multicolumn{4}{|c|}{ Probiyotik besin tüketenler } & \multirow{3}{*}{$\chi^{2} ; \mathbf{p}$} \\
\hline & \multicolumn{2}{|c|}{ Evet } & \multicolumn{2}{|c|}{ Hayır } & \\
\hline & Sayı $(\mathbf{N})$ & Yüzde (\%) & Sayı $(\mathbf{N})$ & Yüzde (\%) & \\
\hline \multicolumn{5}{|l|}{ Cinsiyet } & \multirow{3}{*}{21,$645 ;<0,001$} \\
\hline Erkek & 64 & 56,1 & 50 & 43,9 & \\
\hline Kadın & 382 & 77,4 & 111 & 22,6 & \\
\hline
\end{tabular}


Çalışmamızda probiyotik bilgi düzeyi ile probiyotik besin tüketme durumu arasında anlamlı bir ilişki saptanmış olup probiyotik bilgi düzeyi yüksek olanlar daha çok probiyotik besin tüketmektedir ( $U=25339,0 ; \mathrm{p}<0,001)$ (Tablo 7). Demirel'in üniversite öğrencilerinde yaptığı çalışmada probiyotikler ile ilgili bilgi sorularından aldıkları toplam puanlar ile probiyotik ürünleri tüketim miktarları arasında istatistiksel olarak anlamlı korelasyon saptanmamıştır ( $p>0,05)$ (Demirel 2018). Serinçay'ın tıpta uzmanlık eğitimi alan hekimlerde yaptığı çalışmada probiyotik kelimesinin tanımını bilmekle probiyotik katkılı ürün kullanma arasında anlamlı bir ilişki saptanmamıştır $(\mathrm{p}=0,112)$ (Serinçay 2021). Çalışmamız yapılan diğer çalışmalardan farklılık göstermektedir.

Tablo 7. Öğrencilerin Probiyotik bilgi durumuna göre probiyotik besin tüketme durumu

\begin{tabular}{|c|c|c|c|}
\hline & Probiyotik besin tüketenler $(\mathrm{N}=446)$ & Probiyotik besin tüketmeyenler $(\mathrm{N}=161)$ & $\mathbf{U} ; \mathbf{p}$ \\
\hline $\begin{array}{l}\text { Probiyotikler ile ilgili } \\
\text { bilgi düzeyi toplam } \\
\text { puanı, Ortanca (ÇAA*) }\end{array}$ & $9,0(6,0)$ & $6,0(9,0)$ & $\begin{array}{c}\text { 25339,0; } \\
<0,001\end{array}$ \\
\hline
\end{tabular}

*Çeyrekler arası aralık

\section{Sonuç}

Çalışmamıza katılan öğrencilerin probiyotik bilgi düzeyinin orta düzeyde olduğu saptanmıştır. Çalışmamızda probiyotik bilgi düzeyi yüksek olan öğrenciler daha fazla probiyotik besin tüketmektedir. Bu bakımdan bir besinin tüketilmesinde o besinle ilgili bilgi sahibi olunmasının o besinin tüketilmesini etkilediği düşünülmektedir.

Probiyotik besinler, günümüzün önemli araştırma konularından birini oluşturmaktadır. Geleceğin sağlık çalışanlarının ve öğretmenlerinin probiyotik besinler ile ilgili iyi düzeyde bilgi sahibi olmaları, bu bilgileri aktarabilmeleri ve kendi beslenme planına uyarlayarak topluma örnek olmalarının toplum beslenmesi açısından oldukça önemli olacağı düşünülmektedir.

\section{Kaynakça}

[1] Anukam KC, Osazuwa EO, Reid G. Knowledge Of Probiotics By Nigerian Clinicians. International Journal of Probiotics and Prebiotics, 2006; 1 (1): 57-62.

[2] Aslantürk A. Yetişkin Bireylerin Probiyotik Besinler Hakkında Bilgi Düzeyleri ve Tüketim Durumlarının

Belirlenmesi. Yüksek Lisans Tezi, Haliç Üniversitesi Lisansüstü Ĕ̌itim Enstitüsü, İstanbul, 2019, s. 63.

[3] Aydın M, Açıkgöz İ, Şimşek B. Isparta Süleyman Demirel Üniversitesi Öğrencilerinin Probiyotik Ürün Tüketimlerinin ve

Probiyotik Kavramının Bilinme Düzeyinin Belirlenmesi. Gıda Teknolojileri Elektronik Dergisi 2010; 5 (2): 1-6.

[4] Bakır BO. Prebiyotik, Probiyotik ve Sinbiyotiklere Genel Bakış. Beslenme ve Diyet Dergisi 2012; 40 (2): 178-182.

[5] Balkış M. Lise Öğrencilerinin Beslenme Alışkanlıkları, Probiyotik Süt Ürünleri Tüketim Sıklıkları ve Bilgilerinin Belirlenmesi: Kulu Örneği. Yüksek Lisans Tezi, Selçuk Üniversitesi Sosyal Bilimler Enstitüsü, Konya, 2011, s. 127.

[6] Bilginer Ç, Çetin B. Probiyotikler ve Belirlenmelerinde Kullanılan in vitro Testler. Atatürk Üniv. Ziraat Fak. Derg 2019; 50 (3): 312-325.

[7] Bozkurt H, Aslım B. İmmobilizasyonun Probiyotik Kültürlerde Kullanımı. Orlab On-Line Mikrobiyoloji Dergisi 2004; 2 (7): 1-14.

[8] Ceyhan N, Alıç H. Bağırsak Mikroflorası ve Probiyotikler. Türk Bilimsel Derlemeler Dergisi 2012; 5 (1): 107-113.

[9] Çalıştır B, Dereli F, Eksen M, Aktaş S. Muğla Üniversitesi Öğrencilerinin Beslenme Konusunda Bilgi Düzeylerinin e-ISSN: 2148-2683
Belirlenmesi. Uluslararası Insan Bilimleri Dergisi 2005; 2 (2): $1-8$.

[10] Çoşkun, T. 'Probiyotikler', Teoriden Kliniğe Prebiyotikler Probiyotikler, Eds. Kara A, Çoşkun T, Akademi Yayınevi, İstanbul, 2014, s.56-70.

[11] Demir G, Aktaş N. Üniversite Öğrencilerinin Fonksiyonel Besin Bilgi, Tercih ve Tüketimleri Üzerine Bir Araştırma. Journal of Human Sciences 2018; 15 (4): 2387-2397.

[12] Demirel G. Beslenme Eğitimi Alan ve Almayan Üniversite Öğrencilerinin Probiyotik Besinler Hakkındaki Bilgi Düzeyleri ve Tüketme Durumları Üzerine Bir Araştırma. Yüksek Lisans Tezi, Doğu Akdeniz Üniversitesi Lisansüstü Eğitim, Öğretim ve Araştırma Enstitüsü, Gazimağusa,2018, s. 127.

[13] Derin DÖ, Keskin S. G1da Mühendisliği Öğrencilerinin Probiyotik Ürün Tüketim Durumlarının Belirlenmesi: Ege Üniversitesi Örneği. Glda 2013; 38 (4): 215-222.

[14] Eser AG. Probiyotikler Konusunda Tüketicilerin İlgi ve Kanaatleri (Çanakkale-Biga Örneği). Van Vet J 2017; 28 (1): 25-30.

[15] Gıda, Tarım ve Hayvancılık Bakanlığı.Türk Gıda Kodeksi Etiketleme Yönetmeliği. Resmi Gazete; 29.12.2011. 41 s. Rapor No:28157 (ek 15)

[16] Gomes AMP, Malcata FX. Bifidobacterium spp. and Lactobacillus acidophilus: Biological, biochemical, technological and therapeutical properties relevant for use as probiotics. Trends in Food Science and Technology 1999; 10: $139-157$.

[17] İmamlı H, Akça F. Probiyotik Kullanımının Sağlığa ve Sportif Performansa Etkileri. Spormetre 2018; 16 (2): 196208.

[18] Kağan DA, Özlü T, Yurttaş H. Yetişkin Bireylerin Probiyotik Gıdaları Bilme ve Tüketme Durumları Üzerine Bir Araştırma. Avrupa Bilim ve Teknoloji Dergisi 2019; (17): 556-563.

[19] Kundakçı A, Ergönül B. Probiyotik Gida Nedir? Ne Değildir?. Türkiye 9. Gıda Kongresi, Bolu, 2006, s.93-96.

[20] Öztürk MR. Kadınların Probiyotik Besinler Hakkında Bilgi Düzeyi ve Tüketim Durumlarının Değerlendirilmesi. Yüksek Lisans Tezi, Okan Üniversitesi Săglı Bilimleri Enstitüsü, İstanbul, 2018, s. 70.

[21] Parkes GC. An overview probiotics and prebiotics. Nurs Stand. 2007; 21 (20): 43-47.

[22] Payahoo L, Nikniaz Z, Mahvadi R, Jafar-Abadi MA. perceptions of medical sciences students towards probiotics. Health Promot Perspect 2012; 2(1): 96-102. 
[23] Serinçay H. Tıpta Uzmanlık Eğitimi Alan Hekimlerin Probiyotiler İle İlgili Bilgi Düzeyleri Ve Tutumları. Uzmanlık Tezi, Uludağ Üniversitesi Tıp Fakültesi Aile Hekimliği Anabilim Dalı, Bursa, 2021, s. 67.

[24] Sevilmiş G. Bazı Fonksiyonel Gıdalarda Tüketici Kararları ve Bunları Etkileyen Faktörlerin Belirlenmesi Üzerine Bir Araştırma. Yüksek Lisans Tezi, Ege Üniversitesi Fen Bilimleri Enstitüsü, İzmir, 2008, s. 107.

[25] Stanczak M, Heuberger R. Assessment of the knowledge and beliefs regarding probiotic use. American Journal of Health Education 2009; 40 (4): 207-211.

[26] Şengün IY, Kırmızıgül A, Özaydın İ, Yarım H. Tüketicilerin probiyotik ve prebiyotik gıdalara yönelik bilgi düzeyleri ve tüketim durumlarının belirlenmesi: İzmir/Bornova örneği. GIDA 2020; 45 (1): 103-114.

[27] Usta M, Urgancı N. Çocukluk Çağında Probiyotik Kullanımı. Güncel Pediatri 2014; 12 (2): 88-94.

[28] Yabanc1 N, Şimşek I. Üniversite Öğrencilerinin Probiyotik Ürün Tüketim Durumları. TSK Koruyucu Hekimlik Bülteni 2007; 6 (6): 449-454.

[29] Yalçın S, Yalçın S. 'Probiyotik Gıdalar", Teoriden Kliniğe Prebiyotikler Probiyotikler, Eds. Kara A, Çoşkun T, Akademi Yaylnevi, İstanbul, 2014, s.405-432.

[30] Zemzemoğlu TEA, Uludağ E, Uzun S. Üniversite Öğrencilerinin Probiyotik Bilgi Düzeyi ve Tüketim Durumlarının Belirlenmesi. Glda 2019; 44 (1): 118-130.

[31] Zeren R. Yetişkin Bireylerin Probiyotik Besinler Hakkında Bilgi Düzeyi ve Tüketim Durumlarinin Belirlenmesi. Yüksek Lisans Tezi, Haliç Üniversitesi Sağllk Bilimleri Enstitüsü, İstanbul, 2015, s. 56. 